\title{
The Effectiveness of Media Implementation in Competence-Based Learning Integrated With Character Building in Vocational High Schools
}

\author{
Riana T Mangesa ${ }^{a, 1}$, Dyah Darma Andayani ${ }^{a}$ \\ ${ }^{a}$ Electrical Education Engineering Department \\ Makassar State University, Makassar, INDONESIA \\ ${ }^{1}$ rianamangesa@yahoo.com
}

\begin{abstract}
The use of media in the learning process or in teaching can generate new desires and interests. It can even motivate learning activities that bring the psychological effects on students. In association with the implementation of the curriculum 2013 that emphasize on the values of character, it is necessary to improve capacity, quality and relevance of education. It should be done so that it can be measured to be evaluated according to the achievement of competencies and skills which have character value. The development method used in this research referred to the learning model of Dick and Carey. Then, the developed media was conceptually validated by both experts of content and media. The results showed that the use of visual media developed in an integrated competency-based learning and character education was valid and feasible to be used, because it is more practical and effective.
\end{abstract}

Index Term - learning media, competence-based learning, character education, vocational high school

\section{Introduction}

Vocational education as agent of change has a function and purpose to prepare qualified students in the face of competitive world. Vocational learning system should be able to increase the intelligence, knowledge, personality, noble character, and skills to live independently. The aim is to give the sense that the task of vocational education is to prepare qualified human resources, has the knowledge, independence and being able to adapt and to compete in the real world.

Related to this, the Indonesian Government through Ministry of Education and Culture has tried to develop a grand design of character education in order to improve the quality of education and suitability of students' competence. Based on the curriculum of 2013 and Article 3 of Law 20/2003 on National Education System, it is necessary to develop learning system that serves to build up skills and competence of students. It is also expected to form a noble character in order to dignify human resources to be able to compete in the real world. Therefore, the new curriculum 2013 should be implemented in all schools as an integral part of the overall learning system. This requires the ability of teachers especially those in vocational high schools (Sekolah Menengah Kejuruan or SMK) in planning appropriate competency-based learning system with character value inside.

Along with the implementation of character education in the learning system, the formation of student character can be done through a method of learning that can touch the character values. Teaching the character values to students has to include all potentials within human psychology that can be divided into three parts which are cognitive, affective, and psychomotor. This was supported by Reference [15] that method in learning is to organize students in attempts to reach the goal. Therefore, the method should be made based on steps that required managing learning activities. The use of learning methods that is effective to pass the positive values to students is required to be able to develop good characters.

Moreover, in learning process, teachers need to pay attention that students should have many potential in critical and creative thinking. These potential must be developed through learning activities which are the basis for developing lesson plans and reflected in the basic competencies to be achieved by students.

In line with the efforts to improve the competence of teachers which should be holistically maintained, it tends to produce teachers who are competent in managing the learning activities. A teacher can change student attitudes to become more positive that can be characterized by changes in the knowledge, understanding, attitudes, skills and competencies as well as other aspects of the selflearners.

The revolution of computer technology which followed by the change in information and communication technology has brought many impacts in the world of education. By the introduction computer in learning process, teacher will no longer be the main information resource. Computer will become a tool that can be used to access information through its internet network. Teaching and learning process that were delivered classically with a boring lecture method can now be done directly, individually and fun.

The use of computer technology in schools is one of characters owned by modern schools that always want to improve their quality. Through this technology, a school can expand its accessibility in term of communication, advance its learning resources and can even make its learning process becoming more effective.

The development and utilization of computer technology in the learning process, through the learning media as a tool for teaching and learning process, become a new mean to deliver the knowledge in learning. It is also has to relate with the way of a teacher delivering his teaching material so that it can be used to stimulate thoughts, feelings, concerns, abilities and skills of 
students. This is expected to encourage effective learning process.

Effectiveness in the learning process is the level of achievement of predetermined or planned learning objectives in the learning plan [16].

The effectiveness of learning activities can be viewed from two aspects namely the teacher and student activities. Both of these aspects according Reference [9], are: (a) teaching aspects of teacher which are the things that related to what extent the planned learning process can be conducted well. The better the planning and preparation of teachers, the more effective the learning process; (b) aspects of the students, which concerns the extent to which the learning objectives have been achieved through a process of learning.

Judging from the aspect of teaching, teachers are required to be able to plan a sustainable learning system. Therefore, teachers must be supported by the system readiness and learning tools as an important element in implementing the curriculum. On the other hand, in term of students' aspects, they are expected to be able to add new information or knowledge in accordance with the planned learning objectives.

The entry of the utilization of computers in the learning process has improved learning innovation. It can lead to create more joyful learning process because students can control their learning speed based on their ability. It can be seen from the advent of interactive multimedia technology that could present text, sound, images, animation, and video simultaneously or alternately. With an attractive design learning programs, students are expected to become more interested and diligent in learning process so that it can lead the students to be more smart, creative and innovated.

Learning is an activity in which there is a process of interaction that occurs between teachers and students. Learning can also be interpreted as an information process which aims to assist and motivate students so that problems can be resolved. The success of a teacher can be influenced by the suitability of the learning approach, the media with the material being taught. Therefore, media is one of important factors that can make time used in learning process become more effective.

The results of the survey in 2013, found that lack of knowledge systems in SMK also affected by the lack of a learning device. Some of these schools still implemented conventional learning method such as one way lecturing which followed by the use of board to draw, write something or demonstration ways. Demonstration process becomes less effective if the number of students was high (over 40 people). It requires more time because teachers have to repeatedly perform the demonstration. This will be difficult for the teacher to recall some steps that have been demonstrated and such a situation would be boring for students. Further, motivation to learn becomes lower, which will lead to the situation where students will feel lazy to learn and their ability will not be used optimally. The learning results will lesser and will not reach competence indicator that have been planned before.

In association with these problems, then the corresponding function of the media as a tool for teaching and learning influence climate, conditions and effective learning environment that can be created by the teacher. There will be some use of computer technology as a multimedia application that can help to design the learning process and corresponding activities planned in the lesson plan (RPP, Rencana Pelaksanaan Pembelajaran).

One of the several advantages of learning media is the media can minimize functions of a teacher, so that through the innovative media, learning can take place in the presence of interaction and reciprocity among interactive media with students.

\section{Literature Study and Method}

a. Media Implementation in Learning Process

School as an agent of change is a place to develop intellectual, moral and skill aspects which cannot be reduced to be a single aim of learning. This happens as the success of students in learning depend greatly on whether there are happiness and satisfaction during learning process when repeating and practical process appear inside.

Some education psychology experts ; Reference [10]; [7]; [15] have laid the foundations of the theory of learning which is a theory when there is a change in attitude of individual. It is supported by the thought that an active individual always tends to make effort to think and act in real life. Learning is viewed as a natural process that can bring changes in knowledge, act and behaviour. It is also obvious that the changes of behaviour in learning process is a part of process where students also face similar things that related to the aims and interaction within this process.

Reference [14] argued that learning is one of the ways to develop and deliver information. It is also an activity that may facilitate the achievement of specific goals. An activity that is carried out in such a way by the teacher, can take place inside or outside the classroom, so it can change the appropriate behaviour of learning objectives. Learning can be defined as a permanent influence on knowledge, behaviour and thinking skills acquired through experience. [12].

Related to the context of learning, it will determine the order of learning material delivered in class. Teachers are expected to plan and create more learning experiences about concept and knowledge that will be taught to students.

According to Reference [11], the activities aimed at teachers and students in the learning process should be directed to the purpose of learning that has been specified in the lesson plan. Learning activities involve: (a). Teaching aspects conveyed by teachers that emphasize how the planned learning method will be implemented; (b). Learning aspects by students which determine how the learning aim can be achieved through its process.

Suitability of the application of the lesson plan cannot be separated from the determination of the targeted learning objectives and expected learning outcomes. The learning objectives in general are made based on the three parts of study, namely: process, transfer of learning and how to learn. It is supported by Reference [13] that if learning process occurs in classroom then the class properties tend to be multidimensional. This must be 
understood by the teacher so that the effective interaction can exist in the learning process.

In the interactive learning process, it is necessary to arrange the reciprocal relationship between teachers and students. Innovative learning process by selecting appropriate media should encourage students to learn and initiate inspiration of students. They are expected to come up with more new ideas, develop initiative and creativity.

\section{b. The Effectiveness of Media in Learning}

The development of technology has brought potential changes in learning system. A learning process would be more interesting if there is a right combination between the selections of learning methods with media used in the process. In the process of teaching and learning, multimedia provides a variety of opportunities to apply various methods of learning that can be determined according to the material, facilities and environment.

Instructional media according to Reference [8]; is an interface that carries the message or the information that contains instructional aims or teaching purposes between source and receiver. According to the terminology, the word comes from the Latin media "medium" means an intermediary. Therefore the selection of appropriate learning media, creative and fun can increase motivation to learn, the power of thought and memory of students.

Based on the philosophy of competency-based learning that aimed to achieve competence as individuals, students in the learning process should be able to gradually and individually master the competencies until there is a change in their behavior. Through innovative learning, it can help students to internalize, reshape, or transform new information, by using computer as media. In learning, media has a function to convey the message to students in order to gain a variety of learning experiences, depending on the students' interaction with the media.

According to Reference [2], the main function of learning media teaching is as aids that influence climate, conditions, and the learning environment which is organized and created by the teacher. Utilization of instructional media in teaching and learning can generate new desires and interests, generate motivation and stimulation of learning activities, and even bring a psychological effect on students.

Teaching and learning process is often confronted with abstract material and sometimes it is beyond students' everyday experience. It makes the material becomes more difficult to be taught and to be understand. Therefore, it is important to have media that can be used to stimulate thoughts, feelings, concerns and abilities or skills of students and expected to encourage effective learning process. Effectiveness of learning is the standard or level of achievement of learning goals with a predetermined plan. In the learning process, there are several components that affect the achievement of learning objectives. They are components of the students, teachers, learning objectives, instructional methods, media and evaluation.

To achieve optimal learning objectives, teaching methods need to be considered. The better method of learning used in the process, the more effective achievement of learning objectives can be obtained. Other components that also affect the effectiveness of the method are the atmosphere of learning and roles of the teacher. Teacher will then affect situational factors. These demand every teacher to have ability to manage classes because the more ability of a teacher to make class becoming more active and not crowd, the more effective method that he use in the class. This will lead to have maximal results in learning process.

Reference [2] stated several benefits of media used in the learning process, which are: (1) Learning becomes more attractive so that it can foster students' learning motivation; (2) Learning material becomes easier to be understood and gives more possibility to comprehend and achieve the aim of learning; (3) teaching method will be more varied and no longer only verbal communication by teachers. This makes the learning process will not be a boredom process and teacher, in the other hand, will not easily get tired; (4) students can do more learning activities because they not only listen to the description of the teacher, but also can do other activities such as observing, doing, demonstrating, etc.

Therefore, effective learning is a learning process that uses the right media to implement innovative teaching, through an approach that is more students centered. It provides an opportunity for learners to construct their own knowledge. Reference [9] supported the statement by saying that learning can be said to be effective if the learning is able to provide or add new information or knowledge for students.

\section{Research Method}

This research is an education research and development ( $R \&$ D). Referring to some expert opinions stating that the development of research aims to develop and produce a product in the form of learning devices (materials, methods, media, or learning strategies) which are valid and proved to be success in improving learning in the classroom / laboratory. Reference [4] affirmed that in the field of education, Research \& Developmental ( $R$ \& D) is a process used to develop and validate the products in education.

Procedure of research referred to research stages according to Reference [4] that were modified into five stages, namely: (1) requirement analysis phase; (2) the design development phase; (3) the stage of expert validation and revision; (4) the trial stage; and (5) Evaluation stage.
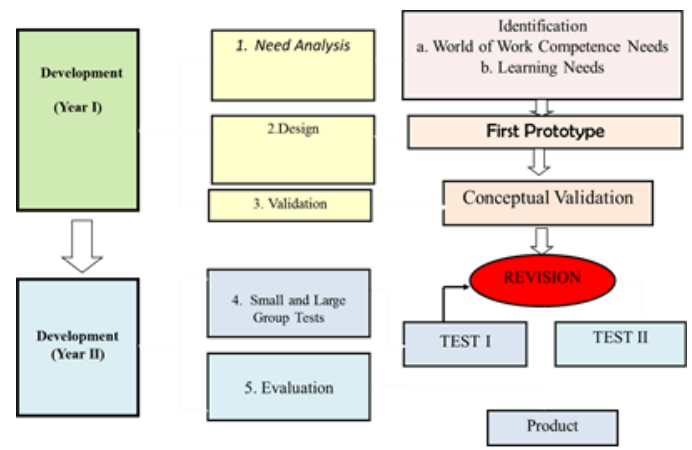

Figure 1. Block Diagram of Development Procedure

At the design stage of the learning, the development of its instructional referred to Reference [6]. Dick and Carey model is an instructional model of learning that is 
effective in the learning process and analysis, with the following activities: (a) determining learning approaches; (b) determining the instructional objectives; (c) specify the performance criteria; (d) determine the learning plan. Specifically on learning approach, the media is developed into a visual media, where the teaching materials, images that require emphasis and explanation visualized in the form of media visualization.

\section{Results and Discussion}

The results of research on small group test showed that the media is feasible and effective. Validation results showed that the developed media has been declared conceptually valid to be used. Validation process was done by three experts and practitioners. Recommendation from them will be used as information to set validity criteria of developed media.

The results and recommendations of the validators will then be used as references to revise the developed media. These also were used to design instrument that will be tested in the field. The media has been tested on a small group. From the results of the data analysis, it can be concluded that in the small group testing, students and teachers provide good response to the effectiveness of the media. The evaluation results have been obtained by testing them to both students and teachers as trial subjects. The results showed good appreciation. It showed that the average score of each instrument is below the mean value of four. Therefore, it still required a minor revision to the extended test so that it can obtain maximum average value. From process view, it can be said that the visual media were very effective in learning process. On the other hand, the results showed that the media can help students to achieve the determined learning aims.

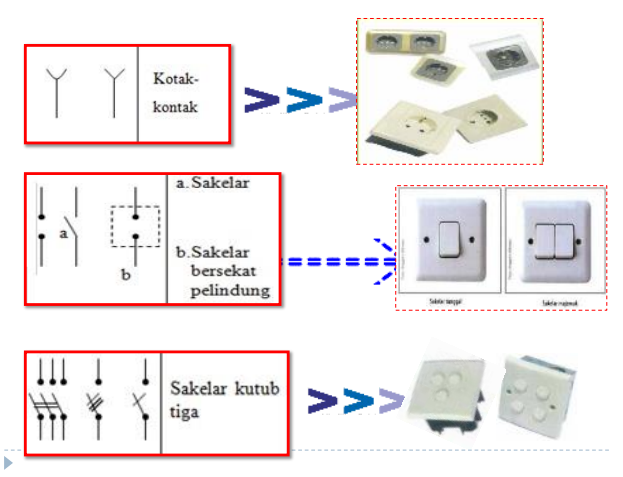

Figure 2. Learning Media

\section{Conclusion}

Based on the results of the development and review of the media, then it can be concluded that learning media meet the criteria of valid and reliable. Products in the form of lesson plans and evaluation tools have been developed according to the indicators of competence to be achieved.

The results showed that with the innovation of the lesson plan and evaluation, learning can be effective if the formed media provide interaction in varying factual concepts and work processes. Through the internalization of the values of characters in the lesson plans, the achievement of competence indicators in the realm of knowledge, attitude and skills will form the good character of students based on the set aims of vocational study.

\section{Acknowledgment}

This research is funded by DIKTI through Competitive Grant Scheme in 2014.

\section{References}

[1] Anderson, Ronald H. (1987). Pemilihan dan Pengembangan Media Untuk Pembelajaran (translated edition by Yusuf Hadi Miarso, et.al). Jakarta: PT.Rajawali.

[2] Arsyad, Azhar (2009). Media Pembelajaran. Jakarta: PT RajaGrafindo Persada

[3] Borich, Gary D.(2007). Effective teaching methods: ResearchBased Practice. Sixth Edition. New York: Pearson Prentice Hall.

[4] Borg, W.R., \& Gall, M.D. (1983). Educational research: An Introduction $\left(4^{\text {nd }}\right.$ ed). New York: Longman. Inc.

[5] Briggs, Leslie, J. (1977). Instructional Design, Principle and Aplication, New York: Mc. Graw Hill Book Company.

[6] Dick, Walter \& Carey, Lou.,Carey, James O. (2001). The Systematic Design Of Instruction (5th ed). New York: Longman.

[7] Gagne, Robert M.(2005). Principles of Instructional Design. New York: Wasdworth Publishing Co.

[8] Heinich, R., Molenda, M., Russell, J. D., \& Smaldino, S.E. (2002) Instructional Media and Technology for Learning, 7th Edition. New Jersey: Prentice Hall, Inc.

[9] Muchith, S. (2008). Pembelajaran Kontekstual. Semarang: RaSAIL Media Group.

[10] Sagala Syaiful. (2010). Konsep dan Makna Pembelajaran: Untuk Membantu Memecahkan Problematika Belajar dan Mengajar. Bandung: Alfabeta.

[11] Sanjaya, Wina (2008). Strategi pembelajaran; berorientasi standar proses pendidikan. Jakarta: Kencana Prenada Media Group.

[12] Santrock, John, W.(2008). Educational psychology and technology 2nd edition .Texas: McGraw-Hill Company, Inc.(original book published in 2004)

[13] Santyasa, I.W.(2007). Model-model Pembelajaran Inovatif. Paper was presented in workshop about Class Action Research for teachers in Nusa Penida

[14] Smith, P.L and Ragan T.L. (2003). Instructional Design : Upper Saddle River. NJ.Prentice Hall.Inc

[15] Sudjana, S (2000). Strategi Pembelajaran. Bandung : Falah Production

[16] Suharsimi Arikunto. (2004). Manajemen pengajaran secara manusiawi. Yogyakarta: PT Rhineka Cipta 